obtained was applied to a paper along with L-serine and authentic $\alpha$-alanine and the chromatogram run in $80 \%$ phenol. Development with ninhydrin showed the product to have the same $R_{F}$ value as $\alpha$-alanine.

2:3-E poxydecanoic acid. Freshly distilled octyl aldehyde (5.7 g.) and ethyl chloroacetate (5.5 g.) in dry ether (100 ml.) were added to sodium methoxide (from $1.0 \mathrm{~g}$. of $\mathrm{Na}$ ) suspended in dry ether. After standing for $48 \mathrm{hr}$. at room temp. water was added, and the ether layer was separated and dried over anhydrous $\mathrm{Na}_{2} \mathrm{SO}_{4}$. The oil left after removal of the solvent was purified by vacuum distillation, yielding ethyl 2:3-epoxydecanoate (6 g., b.p. $90-93^{\circ} / 0 \cdot 1 \mathrm{~mm}$.). Saponification rapidly occurred on the addition of an excess of $12 \%(w / v) \mathrm{KOH}$ in methanol at room temp., with the precipitation of a potassium salt. The mixture was left overnight, diluted with water and carefully acidified with dil. $\mathrm{HCl}$, when the 2:3-epoxydecanoic acid separated as an oil which solidified on standing and was crystallized from light petroleum (b.p. $40-60^{\circ}$ ) in plates, m.p. $59^{\circ}$ (Found: $\mathrm{C}$, $64 \cdot 6$; $\mathrm{H}, 9.5 \%$; equiv. wt. $184 . \mathrm{C}_{10} \mathrm{H}_{18} \mathrm{O}_{3}$ requires $\mathrm{C}, 64 \cdot 5$; $\mathrm{H}, 9 \cdot 7 \%$; equiv. wt. 186). This substance depressed the m.p. of 3-hydroxydecanoic acid, which could possibly have also arisen in the condensation. A solution of the acid in saturated $\mathrm{NaHCO}_{3}$ solution precipitated a sodium salt on standing, and this behaviour was not observed under similar conditions with 3-hydroxydecanoic acid.

Fission of the epoxide ring and regeneration of 2:3-epoxydecanoic acid. (1) The acid (0.5 g.) was dissolved in conc. $\mathrm{HCl}(20 \mathrm{ml}$.) and the mixture heated with frequent shaking on a water bath for $30 \mathrm{~min}$. After dilution with water and extraction with ether, acidic material was removed from the organic phase by saturated $\mathrm{NaHCO}_{3}$ solution. Acidification of the alkaline layer with dil. $\mathrm{HCl}$ yielded chlorohydroxydecanoic acid (0.3 g.), which crystallized from light petroleum (b.p. $40-60^{\circ}$ ) in needles, m.p. 93 (Found: C, 53.9; H, 8.7; $\mathrm{Cl}$, 15.6. $\mathrm{C}_{10} \mathrm{H}_{19} \mathrm{O}_{3} \mathrm{Cl}$ requires $\mathrm{C}, 54 \cdot 0 ; \mathrm{H}, 8 \cdot 6 ; \mathrm{Cl}, 15 \cdot 9 \%$ ).

(2) The chloro acid $(0.2 \mathrm{~g}$.) was added to a solution of $\mathrm{KOH}$ in methanol $(20 \%, \mathrm{w} / \mathrm{v} ; 2 \mathrm{ml}$.). Solid rapidly separated from the mixture, which was stored at room temp. for $2 \mathrm{hr}$. After dilution with water and acidification the product was separated in ether and crystallized from light petroleum (b.p. $\left.40-60^{\circ}\right)$ in plates, $(0 \cdot 15$ g.), m.p. 58-59 , undepressed on admixture with 2:3-epoxydecanoic acid prepared above.
Derivatives of 2-hydroxy-2-methylnonanoic acid. $p$-Nitrobenzoyl chloride $(0 \cdot 1 \mathrm{~g}$.) was added to 2 -hydroxy-2-methylnonanoic acid $(0 \cdot 1 \mathrm{~g}$.$) in dry pyridine (2 \mathrm{ml}$.) and the mixture kept at $56^{\circ}$ for $18 \mathrm{hr}$. To the cooled solution dil. $\mathrm{HCl}$ was added until the odour of pyridine was no longer apparent, and the solid material was filtered off, washed with $\mathrm{NaHCO}_{3}$ solution and water, dried and crystallized from light petroleum (b.p. 80-100 ${ }^{\circ}$ ). 2-Methyl-2-p-nitrobenzoyloxynonanoic acid ( $0.15 \mathrm{~g}$.) separated in cream-coloured needles, m.p. $137^{\circ}$ (Found: $\mathrm{C}, 60 \cdot 5 ; \mathrm{H}, 7 \cdot 0 ; \mathrm{N}, 4 \cdot 0 . \mathrm{C}_{17} \mathrm{H}_{23} \mathrm{O}_{6} \mathrm{~N}$ requires $\mathrm{C}, 60.5 ; \mathrm{H}, 6.9 ; \mathrm{N}, 4.2 \%$ ). The p-bromophenacyl ester of 2-hydroxy-2-methylnonanoic acid was prepared in $80 \%$ yield by refluxing for $1 \mathrm{hr}$. equimolecular quantities of the sodium salt and $p$-bromophenacyl bromide in ethanol. It formed felted needles, m.p. $111^{\circ}$, from light petroleum. (Found: $\mathrm{C}, 56 \cdot 2 ; \mathrm{H}, 6 \cdot 5 ; \mathrm{Br}, 20 \cdot 7$. $\mathrm{C}_{18} \mathrm{H}_{25} \mathrm{O}_{4} \mathrm{Br}$ requires: $\mathrm{C}$, $56 \cdot 1 ; \mathrm{H}, 6 \cdot 5 ; \mathrm{Br}, 20 \cdot 8 \%$ ).

\section{SUMMARY}

1. The acid, $\mathrm{C}_{10} \mathrm{H}_{20} \mathrm{O}_{3}$, from hydrolysis of serratamic acid has been equated with D-3-hydroxydecanoic acid.

2. Racemic serratamic acid and serratamic acid have been synthesized and shown to be the optically inactive and active forms respectively of $N$-(3hydroxydecanoyl)serine.

3. DL-3-Hydroxydecanoic acid has been resolved by fractional crystallization of cinchonidine salts.

4. 2:3-Epoxydecanoic acid has been synthesized.

5. The infrared spectra of serratamic acid and several oxygenated decanoic acids have been recorded.

\section{REFERENCES}

Bergström, S., Theorell, H. \& Davide, H. (1946). Arch. Biochem. 10, 165.

Cartwright, N. J. (1955). Biochem. J. 60, 238.

Maehlmann, H. (1915). Chem. Zbl. 11, 1178.

Sakami, W. \& Toennies, G. (1942). J. biol. Chem. 144, 203.

Serck-Hanssen, K. (1956). Arkiv. Kemi, 10, 135.

Serck-Hanssen, K. \& Stenhagen, E. (1955). Acta chem. scand. 9, 866 .

\title{
Synthesis of Cellulose by Acetobacter xylinum
}

\section{SUBSTRATES AND INHIBITORS*}

\author{
BY M. SCHRAMM, Z. GROMET AND SHLOMO HESTRIN \\ Laboratory of Microbiological Chemistry of the Department of Biochemistry, \\ Hebrew University-Hadassah Medical School, Jerusalem, Israel
}

\section{(Received 12 April 1957)}

Earlier communications described a microassay of cellulose (Schramm \& Hestrin, 1954 $a$ ) and the preparation of Acetobacter xylinum as a fibril-free, stable suspension of washed non-proliferating cells

* Part 2: Hestrin \& Schramm (1954). For a preliminary communication on some experiments described in the present paper and results obtained in a tracer analysis of cellulose production, see Schramm, Gromet \& Hestrin (1957). of high cellulose-synthesizing potency (Hestrin \& Schramm, 1954). It was hoped that with the aid of these tools an effective approach could be made to unsolved problems in the chemistry and mechanics of cellulose production, and indeed that it might not be difficult to effect a separation of the cellulosesynthesizing enzyme system from the structure of the cell. However, this hope has not been fulfilled. 
In the absence of a soluble preparation of cellulosesynthesizing enzyme, the investigation has been restricted to the consideration of the behaviour of whole cells in suspension.

The substrate range of the production of cellulose and carbon dioxide in a suspension of washed A. xylinum cells, carbon balances and some effects of inhibitors on the pattern of carbohydrate metabolism are reported here. The oxidation of glucose via gluconate to oxogluconates (OGn) and conversions of hexoses (glucose, fructose) and gluconate into hexose phosphate (hexose-P) and carbon dioxide in a cell-free extract of this bacterium are described in the next paper (part 4; Gromet, Schramm \& Hestrin, 1957).

\section{MATERIALS AND METHODS}

Preparation of cell suspension. The strain of A. xylinum was the same as that employed in earlier investigations (Hestrin \& Schramm, 1954; Schramm \& Hestrin, 1954a). Except as otherwise indicated, washed glucose-grown cells were used. Mass cultures were grown at $30^{\circ}$ on shallow layers of quiescent liquid contained in aluminum pans under loose covers.

The composition of the glucose medium was as follows: glucose $2 \%$, Marmite $0.25 \%$, yeast extract (Difco) $0.25 \%$, bactopeptone (Difco) $0.5 \%$, dipotassium phosphate $0.1 \%$; $\mathrm{pH}$ 7. The crop was collected after $36 \mathrm{hr}$. This choice of time was of importance, as a rapid decline in the cellulosesynthesizing activity accompanied ageing of the cells in this culture medium.

The fructose medium was of the following composition: fructose $2 \%$, yeast extract (Difco) $0.4 \%$, bactopeptone (Difco) $0.3 \%$, L-asparagine $0.1 \%$; pH 5. After the cells had been maintained on this medium for several passages, they were grown on it on a larger scale. The crop was collected after incubation for $48 \mathrm{hr}$.

Cells were removed from the pellicles as described previously (Hestrin \& Schramm, 1954). The cells were washed first in a dilute solution (pH 5) containing $32 \mathrm{~mm}$ sodium phosphate and $16 \mathrm{~mm}$-citrate, and then in successive changes of water. All the operations were carried out in the cold.

The washed cells were stored at $-20^{\circ}$ as a lyophilized powder ('freeze-dried cells'). In these conditions their cellulose-synthesizing power declined slowly, generally by less than $30 \%$ in the first 2 weeks. Cells suspended in the phosphate-citrate buffer ( $\mathrm{pH} 5$ ) could be stored for several weeks with good retention of activity in the form of a frozen cake ('frozen cells').

Composition of test system. Reaction mixtures contained cells, substrate, oxygen and an appropriate buffer (e.g. sodium citrate solution, $\mathrm{pH} \mathrm{6.4)}$ in a closed vessel at $30 \pm 0 \cdot 2^{\circ}$. The mixture was agitated by shaking in a water bath at 100 oscillations/min. Synthesis of cellulose was stopped at any desired time by flooding the mixture with ether.

Substrates. $\beta$-Glucose 1-phosphate ( $\beta$-G 1-P) was synthesized enzymically from maltose (Fitting \& Doudoroff, 1952). The enzyme preparation was a maltose phosphorylase from a strain of Neisseria meningitidis (type I).
5-Oxogluconate $(5-\mathrm{OGn})$, synthesized by Killiani's method (Barch, 1933), was purified by successive recrystallizations. Calcium 2-oxogluconate (2-OGn) was a pure preparation kindly given to us by $\mathrm{Dr} B$. Horecker. Uridine diphophoglucose (UDPG) was a preparation of medium purity kindly given to us by $\mathrm{Dr}$ L. Leloir. Sedoheptulose was in equilibrium with sedoheptulosan (Ujejski \& Waygood, 1954). Ribose 5-phosphate (R 5-P) was separated from a partial hydrolysate of adenosine monophosphate (Khym \& Cohn, 1953). Glucose 4-phosphate (G 4-P) was kindly given by Dr F. Reithel. It was impure, but as only a small amount was available we used it directly. A specimen of polylysine was kindly provided by Dr E. Katchalski. Other compounds were from commercial sources. Barium and calcium salts were converted before use into their soluble $\mathrm{Na}^{+}$ion forms.

Quantitative analytical methods. The gas exchanges were measured manometrically. Carbon dioxide in the gas phase was removed continuously by alkali in a central cup. In the suspension of the washed fresh or freeze-dried cells, the endogenous rates both of respiration and cellulose synthesis were negligible or nil. To obtain values of cellulose synthesis, the amount of cellulose initially present was deducted from the total amount found after incubation of cells with substrate. The initial cellulose values were less than $20 \%$ of the amounts of cellulose formed during the incubation with glucose.

Reducing power (as glucose) was determined with Somogyi's copper reagent (Nelson, 1944), cellulose by our micro-method (Schramm \& Hestrin, 1954b), 2-OGn by its reaction with $o$-phenylenediamine (Lanning \& Cohen, 1951) and 5-OGn with 1-methyl-1-phenylhydrazine sulphate (Schramm, 1956). Relative reducing powers of glucose, 2-OGn and 5-OGn towards the copper reagent were $1 \cdot 00: 0 \cdot 75: 0 \cdot 55$. In the presence of $O G n$ glucose was measured iodometrically (Macleod \& Robison, 1929). Pyruvate was estimated according to Friedemann \& Haugen (1943).

Chromatographic procedure. The chromatograms were prepared on Whatman no. 1 filter paper. Solvent systems were (1) butanol-acetic acid-water (4:1:5, by vol.), (2) methanol-ethanol-water $(9: 9: 2$, by vol.) and (3) phenol saturated with water. The development times were 54, 24 and $32 \mathrm{hr}$. respectively.

Reducing substances were detected on paper with alkaline dinitrosalicylate (Jeanes, Wise \& Dimler, 1951). Aniline oxalate (Horrocks, 1949) gave characteristic colour reactions distinguishing respectively glucose, 2- and 5-OGn (see Table 3). Acid substances were located with bromophenol blue indicator. Acetic acid, separated by distillation, was identified on the basis of mobility on paper in a solvent system (Jones, Dowling \& Skraba, 1953) containing butanolwater-diethylamine (100:15: 1, by vol.).

\section{EXPERIMENTAL AND RESULTS}

\section{Survey of substrates}

Ranges of substrate for bacterial cellulose production have been described previously by several investigators (Brown, 1886; Tarr \& Hibbert, 1931 ; Khouvine, 1936; Hestrin, Aschner \& Mager, 1947; Kaushal \& Walker, 1951; Barclay, Bourne, Stacey \& Webb, 1954). As almost all the earlier work was 
Table 1. Substrate range of washed glucose-grown cells of A. xylinum

Activities are calculated on a basis relative to that of glucose $(=10)$ for the same conditions of substrate concentration and $\mathrm{pH}$ of medium. Reaction rates $[\mu \mathrm{moles} / \mathrm{mg}$. of cells $(\mathrm{dry} \mathrm{wt}.) / \mathrm{hr}$.] with glucose ranged, depending on assay conditions and cell preparation, within the following limits: uptake of $\mathrm{O}_{2}$ and formation of $\mathrm{CO}_{2}, 1 \cdot 5-5$ (measured within the interval 0-30 min.); formation of cellulose monomer, 0.1-0.4 (measured at the end of the interval 0-1 or 0-2 hr.). The reaction mixture contained 5-10 mg. (dry wt.) of cells. The final volume was $2 \mathrm{ml}$. with air as gas phase and $25 \mathrm{~mm}$-citrate $+50 \mathrm{mM}$ sodium phosphate as buffer in the experiments with fresh cells, and $20 \mathrm{ml}$. with $\mathrm{O}_{2}$ as gas phase and as buffer $20 \mathrm{~mm}$ sodium citrate at $\mathrm{pH} 6.4$ and $40 \mathrm{mM}-2$-amino-2-hydroxymethylpropane-1:3-diol at $\mathrm{pH} \mathrm{7.5}$ in the experiments with freezedried cells. The rates of gas exchange were all maximal or nearly so from the outset of reaction and did not fall off markedly within the period of measurement. Values of the respiratory quotient (R.Q.) were determined for the reaction interval 0-30 min.

\begin{tabular}{|c|c|c|c|c|c|c|c|c|c|c|}
\hline \multirow[b]{3}{*}{ Compound } & \multirow{3}{*}{$\begin{array}{l}\text { Concn. } \\
\text { (mM) }\end{array}$} & \multirow[b]{3}{*}{$\mathrm{pH}$} & \multicolumn{8}{|c|}{ Activity of cells (glucose $=10$ ) } \\
\hline & & & \multicolumn{4}{|c|}{ Fresh cells } & \multicolumn{4}{|c|}{ Freeze-dried cells } \\
\hline & & & Cellulose & $\mathrm{O}_{2}$ & $\mathrm{CO}_{2}$ & R.Q. & Cellulose & $\mathrm{O}_{2}$ & $\mathrm{CO}_{2}$ & R.Q. \\
\hline Gluconate & 5 & $6 \cdot 4$ & - & 4 & 7 & $1 \cdot 0$ & 4 & 4 & 8 & $1 \cdot 0$ \\
\hline $2-0 G n$ & $\begin{array}{c}5 \\
20 \\
7 \cdot 5 \\
7 \cdot 5\end{array}$ & $\begin{array}{l}6.4 \\
7 \cdot 5 \\
6 \cdot 4 \\
\mathbf{4} \cdot 0 \dagger\end{array}$ & $\frac{\overline{-}}{\mathbf{4}^{*}}$ & $\begin{array}{c}\bar{Z} \\
\mathbf{6} \\
2\end{array}$ & $\overline{\overline{11}}$ & $\begin{array}{l}\bar{Z} \\
1.0 \\
1.0\end{array}$ & $\begin{array}{l}0 \\
0 \\
- \\
-\end{array}$ & $\begin{array}{l}0.5 \\
-\end{array}$ & $\frac{1}{二}$ & $\begin{array}{l}1.0 \\
\text { - }\end{array}$ \\
\hline 5.OGn & $\begin{array}{l}7 \cdot 5 \\
7 \cdot 5 \\
20 \\
20\end{array}$ & $\begin{array}{l}\mathbf{6 . 4} \\
\mathbf{4 . 0} 0 \dagger \\
\mathbf{6 . 4} \\
\mathbf{7 . 5}\end{array}$ & $\begin{array}{l}\mathbf{1}^{*} \ddagger \\
-\end{array}$ & $\begin{array}{r}3 \\
7 \\
-\end{array}$ & $\begin{array}{r}5 \\
11 \\
-\end{array}$ & $\begin{array}{l}1.0 \\
1.2 \\
-\end{array}$ & $\begin{array}{c}\overline{-} \\
0 \\
0\end{array}$ & $\bar{z}$ & z & E \\
\hline Fructose & 160 & 6.4 & - & - & - & - & $0 \S$ & $\mathbf{0}$ & 0 & - \\
\hline Glycerol, DHA & 40 & $\begin{array}{l}6.4 \\
7.5\end{array}$ & 二 & $=$ & 二 & - & $\begin{array}{r}1 \\
10\end{array}$ & - & - & - \\
\hline Cellobiose, maltose & 160 & $6 \cdot 4$ & - & - & - & - & 1 & - & - & - \\
\hline G 6-P, $\alpha-G$ 1-P & 40 & $6 \cdot 4$ & - & - & - & - & $0 \|$ & - & - & - \\
\hline Other P-esters T & 40 & $6 \cdot 4$ & - & - & - & - & 0 & - & - & - \\
\hline Other compounds** & 160 & $6 \cdot 4$ & - & - & - & - & 0 & - & - & - \\
\hline
\end{tabular}

* This number was calculated on the basis of values found at a reaction time of $7 \mathrm{hr}$.

$\dagger$ At this $\mathrm{pH}$, though not at $\mathrm{pH} 6.4$, citrate probably contributed appreciably to the observed respiration, values of $\mathrm{O}_{\mathbf{2}}$ uptake and $\mathrm{CO}_{2}$ formation with citrate alone being 1 and 2 respectively, at $\mathrm{pH} 4$ as compared to $<0.5$ at $\mathrm{pH} 6.4$. Values presented in the Table are after deduction of the citrate rates from the rate observed in the presence of added substrate.

† Trace of cellulose.

Orthophosphate was not found to have been released into the medium.

If $\beta$-G 1-P, UDPG, G 4-P (crude), fructose 1:6-diphosphate (F 1:6-P), and R 5-P.

** Pentoses (D-xylose, D-ribose, L-arabinose), some hexoses (D-mannose, D-galactose, L-sorbose), sedoheptulose, several saccharides (sucrose, $\alpha \alpha$-trehalose, lactose, Schardinger $\alpha$-dextrin, partial hydrolysate of dextran, starch; mm is expressed as to hexose), sorbitol, L-ascorbate, glycerophosphate, ethanol, acetate, pyruvate and lactate.

\section{Table 2. Substrate range of washed fructose-grown cells}

Reaction mixtures ( $2 \mathrm{ml}$.) contained $15 \mathrm{mg}$. (dry wt.) of cells and 7.5 mM-substrate in 20 mM-sodium citrate buffer, pH 6.4. The gas phase was air. For explanation of units of measurement, see legend to Table 1.

\begin{tabular}{lccc} 
Added & \multicolumn{3}{c}{ Reaction rates } \\
\cline { 2 - 4 } substrate & Cellulose* & $\mathrm{O}_{2}$ & $\mathrm{CO}_{2}$ \\
$\begin{array}{l}\text { Glucose } \\
\text { Acetate } \dagger\end{array}$ & $10(10)$ & 10 & 10 \\
Pyruvate & 0 & 3 & - \\
Fructose & $10(11)$ & 4 & 6 \\
Gluconate & $-(14)$ & - & -
\end{tabular}

* Values in parentheses give results found in a parallel experiment in which $300 \mathrm{~mm}$-substrate was employed with $\mathrm{O}_{2}$ as gas phase.

† Completely oxidized to $\mathrm{CO}_{2}$. done on growing cultures it did not distinguish between a possible effect of a substrate on cell growth from one on cellulose production. By using washed non-proliferating cells in the present investigation, this source of ambiguity could be eliminated.

Cellulose was formed by washed cells of $A$. xylinum from dihydroxyacetone (DHA), glycerol, fructose, glucose, gluconate, 2-OGn and 5-OGn (Tables 1 and 2). The range of substrates yielding $\mathrm{CO}_{2}$ on oxidation by these cells at $\mathrm{pH} 6.4$ not only comprised cellulose-forming substrates but also others, such as acetate (tested in citrate buffer) and pyruvate, succinate, fumarate, L-malate, oxaloacetate and $\alpha$-oxoglutarate (all tested in phosphate buffer). Citrate, like isocitrate, gave no cellulose at either $\mathrm{pH} 6.4$ or 4.0 ; it was oxidized at $\mathrm{pH} 6.4$ 
sluggishly, if at all; however, its oxidation rate was significant at pH 4 (Table 1). Although acetate and lactate have not been converted into cellulose either in a growing culture of $A$. xylinum (Greathouse, Shirk \& Minor, 1954) or in the washed-cell suspension, they have been found to be converted into cellulose in a growing culture of $A$. acetigenum (Bourne \& Weigel, 1954; Stacey, 1954).

The range of substrates for both cellulose and $\mathrm{CO}_{2}$ formation depended on the cell history and on the conditions of the assay. An adaptive effect of carbohydrate composition of the growth medium on the substrate range is illustrated by the behaviour of the washed cell towards fructose (cf. Tables 1 and 2). Effects of pH of the assay system are illustrated by the findings with citrate, 5-OGn, DHA and DHA-forming glycerol; a restrictive effect of freeze-drying is shown by 2-OGn (Table 1).

\section{Carbon balances of hexose transformation}

Freeze-dried and fresh cells both formed the same products from glucose (Table 3). These were (a) native high-polymer cellulose found in the extracellular phase (Hestrin \& Schramm, 1954), (b) $\mathrm{CO}_{2}$, (c) gluconate (see also Brown, 1886) which could be demonstrated in the medium within minutes after contact of the cells with glucose but could no longer be detected once rapid production of cellulose had come to an end, and $(d)$ two oxogluconates identified as 2- and 5-OGn. In the suspension of freeze-dried cells and in one of fresh cells in glucose medium, the ratio 2-OGn:5-OGn was 2 : 1 (see also Kulka \& Walker, 1954).

The amounts of cellulose formed from hexose (glucose, fructose) were not altered noticeably when $\mathrm{CO}_{2}$ was removed continuously from the gas phase. On the assumption that $\mathrm{CO}_{2}$ production, like that of cellulose, does not depend on $\mathrm{CO}_{2}$ in the gas phase, Warburg's direct method could be used as a means of estimating $\mathrm{CO}_{2}$ production. Carbon balances drawn up in this manner are collected in Table 4. The analytical recoveries of carbon in the experiments with glucose are $>84 \%$, i.e. within the probable range of the accumulative error of the analyses. Within these limits, the balance sheets of the glucose transformation could be described by the following empirical equation:

(s) glucose $+(6 p+q) \mathrm{O}_{2} \rightarrow$

$(6 p) \mathrm{CO}_{2}+(q)$ OGn $+(r)$ cellulose monomer

$$
+(6 p+q+r-1) \mathrm{H}_{2} \mathrm{O} \text {, }
$$

where $s=p+q+r$ (moles) and $r$ is the degree of polymerization of the cellulose.

A carbon balance for fructose is included in Table 4. In this experiment, the substrate was in the form of $\left[{ }^{1-14} \mathrm{C}\right]$ fructose. The reported analytical deficit $(11 \%)$ is only slightly greater than the probable cumulative error of the analytical methods used. At the time of the drawing up of the balance sheet, the copper-reducing power of the medium was $5 \%$ of the initial value and the quotient ${ }^{14} \mathrm{C} /$ reducing power' was $200 \%$ of that of fructose. [The persisting reducing product in this reaction mixture could conceivably have been a disaccharide (cf. Wright \& Walker, 1955)]. In accordance with the conclusion that the only oxidation product formed and accumulated in substantial amount in this system was $\mathrm{CO}_{2}$, the R.Q. of fructose was found to be 1.0 throughout the reaction.

In different batches of fresh and dried cells there were marked variations in the percentage of glucose converted into cellulose, of glucose converted into $\mathrm{OGn}$, ratio of $\mathrm{OGn}$ to $\mathrm{CO}_{2}$, ratio of cellulose to $\mathrm{OGn}$, ratio of cellulose to glucose converted into $\mathrm{CO}_{2}$ $(r / p)$ and ratio of cellulose to $\mathrm{O}_{2}$ uptake $[r / 2(q+6 p)]$ (Table 4). Since freeze-dried cells oxidized OGn much more slowly than they did glucose or gluconate, the net amounts of OGn found in the suspensions of freeze-dried cells in glucose solution are probably only slightly less than the gross amounts.

Table 3. Hexonates formed by A. xylinum from glucose and gluconate

The test mixture contained $15 \mathrm{mg}$. of freeze-dried cells and $50 \mathrm{mg}$. of substrate in $5 \mathrm{ml}$. of water under $\mathrm{O}_{2}$; the pH was maintained at 5 by intermittent alkali addition. The reaction time was $2 \mathrm{hr}$. For analysis the reaction mixtures were cleared by centrifuging and passed through a cation-exchange column (Amberlite IR 100, $\mathrm{H}^{+}$). The effluents were reduced in volume by freeze-drying and then examined by paper chromatography. A control experiment in which the $A$. xylinum cell suspension was incubated without substrate gave negative reactions in all the tests listed in the Table.

\begin{tabular}{|c|c|c|c|c|c|c|c|c|}
\hline \multirow[b]{3}{*}{ Compound } & \multicolumn{6}{|c|}{ Properties of compound } & \multirow{2}{*}{\multicolumn{2}{|c|}{$\begin{array}{l}\text { Formation of } \\
\text { compound from } \\
\text { substrates }\end{array}$}} \\
\hline & \multicolumn{3}{|c|}{$R$ in solvents $\dagger$} & \multirow{2}{*}{$\begin{array}{l}\text { Acid } \\
\text { group }\end{array}$} & \multirow{2}{*}{$\begin{array}{l}\text { Free } \\
\text { reducing } \\
\text { group }\end{array}$} & \multirow{2}{*}{$\begin{array}{c}\text { Colour with } \\
\text { aniline oxalate }\end{array}$} & & \\
\hline & 1 & 2 & 3 & & & & Glucose & Gluconate \\
\hline thlucose & $1 \cdot 00$ & 1.00 & 1.00 & - & + & Brown & & \\
\hline OGn & 0.55 & $0 \cdot 75$ & 0.55 & + & + & Red & + & + \\
\hline -OGn & $1 \cdot 32$ & $0 \cdot 60$ & $0 \cdot 61$ & + & + & Yellow & + & + \\
\hline Gluconate & $1 \cdot 05$ & 0.56 & $0 \cdot 82$ & + & - & None & + & \\
\hline 2:5-Dioxogluconate* & 0.55 & • & . & + & + & Green-yellow & - & - \\
\hline
\end{tabular}


Table 4. Carbon balances of aerobic transformation of glucose and fructose

Reaction mixtures $(2 \mathrm{ml}$.) varied as to composition within the following ranges: cells, 8-15 mg. (dry wt.); substrate, 2.5-7.5 mM; buffer, 4-20 mM-sodium citrate, $\mathrm{pH}$ 6.4. The gas phase was $\mathrm{O}_{2}$. The analysis was carried out at the end of 4-5 hr. of reaction. At this time, originally added substrate and intermediately formed gluconate had been consumed, the cellulose synthesis was at a standstill and the rate of $\mathrm{CO}_{2}$ formation had recently fallen markedly. For the significance of $p, q$, and $r$ see eqn. (1).

\begin{tabular}{|c|c|c|}
\hline \multirow{2}{*}{$\begin{array}{c}\text { Expt. } \\
\text { no. }\end{array}$} & \multicolumn{2}{|c|}{ Cells } \\
\hline & Batch & Condition \\
\hline 1 & $a$ & Freeze-dried \\
\hline 2 & $b$ & Freeze-dried \\
\hline 3 & $c$ & Fresh \\
\hline $4^{*}$ & $d$ & Fresh \\
\hline 5 & $e$ & Fresh \\
\hline 6 & $e$ & Fresh \\
\hline
\end{tabular}

Sugar in
growth
medium
Glucose
Glucose
Glucose
Glucose
Fructose
Fructose

Analytically determined products (initially added hexose $=100$ )

$\begin{array}{cc}\text { Total analytical } \\ \text { Expt. } & \begin{array}{c}\text { recovery of added } \\ \text { substrate } \\ \text { (carbon, \%) }\end{array} \\ \text { no. } & 84 \\ 1 & 84 \\ 2 & 103 \\ 3 & 103 \\ 4 & 100 \\ 5 & 89\end{array}$

Calculations

Substrate
Glucose
Glucose
Glucose
Glucose
Glucose
Fructose
ations

Cellulose monomer $\mathrm{CO}_{2}$ (as glucose)
$(r / p)$

$1 \cdot 7$

$1 \cdot 6$

$1 \cdot 1$

$0 \cdot 7$

$0 \cdot 4$

0.5

$\begin{array}{ccc}\mathrm{CO}_{2} & 2-\mathrm{OGn}+5-\mathrm{OGn} & \begin{array}{c}\text { Cellulose } \\ (p)\end{array} \\ (q) & (q) & 20 \\ 12 & 32+20 & 33 \\ 21 & 21+9 & 46 \\ 40 & 12+5 & 40 \\ 58 & 5 \dagger & 27 \\ 70 & 3 \dagger & 28\end{array}$

* Gas phase: air.

$\dagger$ Calculated from the persisting copper-reducing power of the reaction mixture on the basis of the assumption that the ratio '2-OGn:5-OGn' was 2.

$\ddagger$ Calculated on the assumption that $q=0$.

Thus the listed values of the ratio $q / p$ of freeze-dried cells can be taken as a rough index of relative activity of alternate metabolic pathways. Increases in $q / p$ are known to accompany the ageing of Acetobacter spp. in culture (Butlin, 1938; Kluyver \& Boezaardt, 1938). In a washed $A$. xylinum cell, this phenomenon appears to have been produced by freeze-drying, probably because such treatment selectively injured a component of the mechanism of OGn oxidation. As no pair of the $p, q$ or $r$ terms observed a constant relationship in this series of experiments, it seems probable that $q$ and $p$ comprised components which are facultatively dissociable from $r$.

\section{Gluconate as an intermediate of glucose metabolism}

Gluconate gave the same products of reaction as glucose (Table 3). It was itself formed much more rapidly from glucose than was either $\mathrm{CO}_{2}$ or cellulose. Thus at a low glucose concentration ( $₹ 10 \mathrm{~mm}$ ), the R.Q. of glucose oxidation by freeze-dried cells was initially low $(<0.5)$ for a short time (Fig. 1), but at high glucose concentration ( $100 \mathrm{~mm}$ ) in this system the period of low R.Q. persisted for at least $1 \mathrm{hr}$. At the higher concentration of substrate the amount of gluconate (total non-volatile acid minus total OGn) formed in $1 \mathrm{hr}$. exceeded several-fold the equivalent of the sum of all the other reaction products $\left(\mathrm{CO}_{2}\right.$,

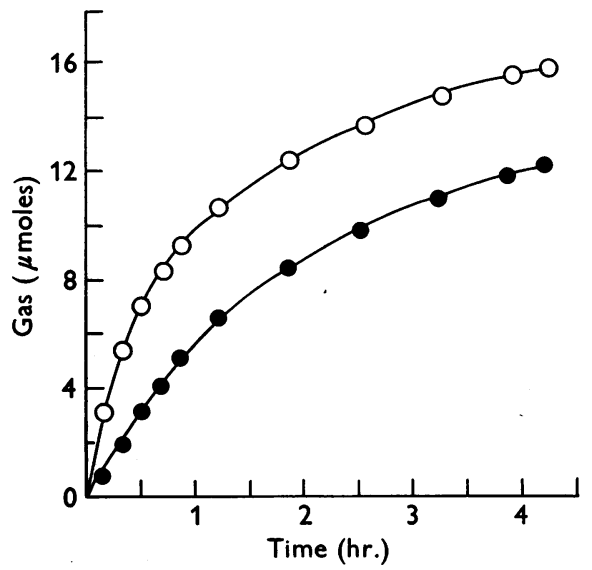

Fig. 1. Course of oxidation of glucose by freeze-dried cells. Reaction mixture $(2 \mathrm{ml}$.) contained $15 \mathrm{mg}$. of cells, $5 \mathrm{~mm}$-glucose and $10 \mathrm{~mm}$-sodium citrate, $\mathrm{pH} 6 \cdot 4$. The gas phase was $\mathrm{O}_{2}$. $\mathrm{O}, \mathrm{O}_{2}$ uptake;, $\mathrm{CO}_{2}$ evolution.

cellulose and OGn). With a suspension of fresh cells (Expt. 4 in Table 4) and $2.5 \mathrm{~mm}$-glucose, the net amounts of gluconate, $\mathrm{CO}_{2}$ and cellulose formed were found to be respectively (as \% of initial glucose) : 60, 7 and 8 after 10 min.; 0,58 and 40 after $5 \mathrm{hr}$. Such data require that the bulk of cellulose and 
$\mathrm{CO}_{2}$ were formed via gluconate formed intermediately in these cell preparations.

Time-courses of the production of cellulose from added glucose and gluconate are compared in Fig. 2. It can be seen that gluconate was inferior as a substrate to glucose during the first hour of reaction but that the subsequent course and magnitude of the synthesis from both 'glucose' and gluconate became practically identical. Since glucose supported a more rapid initial synthesis than did gluconate, it could be supposed either that gluconate entered the cells less rapidly than did glucose, or that gluconate was a facultative but not an obligatory intermediate of synthesis from glucose.

\section{Anaerobic systems}

Cellulose was not synthesized under $\mathrm{N}_{2}$ as gas phase in systems containing glucose and added electron acceptors other than $\mathrm{O}_{2}$ (Table 5). In the



Fig. 2. Course of synthesis of cellulose from glucose and gluconate by freeze-dried cells. Reaction mixtures (2 ml.) contained $10 \mathrm{mg}$. of cells, $5 \mathrm{~mm}$-substrate (glucose or gluconate) and 10 mM-sodium citrate, $\mathrm{pH} \mathrm{6.4.} \mathrm{Gas}$ phase was $\mathrm{O}_{2}$. O, Glucose; 0 gluconate. absence of an added electron acceptor, glucose was not attacked. The addition of several dyes (e.g. 2:3:5-triphenyltetrazolium salt and 2:6-dichlorophenolindophenol), which are known to enter into reaction with flavins, allowed the rapid oxidation of glucose and gluconate but did not permit formation of either cellulose or $\mathrm{CO}_{2}$. The ability to oxidize gluconate by the action of dyes distinguishes the OGn-forming system in $A$. xylinum from that in some other OGn-forming bacteria (cf. Wood, 1955).

The addition of adenosine triphosphate (ATP) failed to initiate the anaerobic synthesis of cellulose from glucose or gluconate, nor was the ATP hydrolysed [cells in 2-amino-2-hydroxymethylpropane-1:3-diol (tris) buffer at $\mathrm{pH} 7$ with added $\mathrm{Mg}^{2+}$ ions]. An introduction of $\mathrm{O}_{2}$ into this system promptly initiated cellulose synthesis.

Pyruvate was rapidly metabolized anaerobically, affording 1 mole of $\mathrm{CO}_{2}, 0.5 \mathrm{~mole}$ of acetate (identified chromatographically) and, presumably, 0.5 mole of ethanol (cf. Stephenson, 1949)/mole of utilized pyruvate.

\section{Modification of the pattern of glucose metabolism by inhibitors}

Compounds that have been tested for ability to inhibit cellulose synthesis from glucose are listed in Table 6 in their probable order of descending potency.

Fluoride. Cellulose synthesis from glucose in citrate medium was blocked by $10 \mathrm{~mm}$-fluoride both in the presence and absence of added orthophosphate (5 mM) (Table 7). Carbon dioxide formation in this system was retarded significantly, but not blocked, by fluoride acting in the absence of added orthophosphate. However, no effect of fluoride on $\mathrm{CO}_{2}$ production occurred in the presence of added orthophosphate (Fig. 3; cf. also, Hestrin et al. 1947). The oxidation of glucose by cells poisoned by fluoride in citrate medium with added orthophosphate proceeded smoothly until practically all of the glucose had been converted into $\mathrm{CO}_{2}$.

Table 5. Anaerobic oxidation of glucose and gluconate by addition of electron acceptors to a suspension of cells

Reaction mixtures $(3 \mathrm{ml}$.) contained $8 \mathrm{mg}$. (dry wt.) of fresh cells, mM-substrate (glucose or gluconate) and $10 \mathrm{~mm}$ added electron acceptor in $10 \mathrm{~mm}$-sodium citrate, $\mathrm{pH} \mathrm{6.4}$, under $\mathrm{N}_{2}$. Without added substrate a relatively slow reduction of added eleotron acceptors occurred. + +, Rapid reaction; \pm very sluggish reaction (slightly faster than that of system without added substrate); 0 , no reaction. In a similar experiment with freeze-dried cells, all the alternate acceptors listed below were rapidly reduced both by glucose and gluconate without attendant cellulose synthesis. When $\mathrm{O}_{2}$ was introduced into these systems, rapid synthesis of cellulose occurred.

\begin{tabular}{ll} 
Substrate & \multicolumn{1}{c}{ Electron acceptor } \\
Glucose & 2:6-Dichlorophenolindophenol \\
Gluconate & 2:6-Dichlorophenolindophenol \\
Glucose & 2:3:5-Triphenyltetrazolium \\
Gluconate & 2:3:5-Triphenyltetrazolium \\
Glucose & Ferricyanide
\end{tabular}

Substrate

Gluconato

Glucose

Glucose

\begin{tabular}{|c|c|c|}
\hline \multicolumn{3}{|c|}{ Activity } \\
\hline $\begin{array}{l}\text { Reduction } \\
\text { of acceptor }\end{array}$ & $\begin{array}{l}\text { Formation } \\
\text { of cellulose }\end{array}$ & $\begin{array}{c}\text { Formation } \\
\text { of } \mathrm{CO}_{2}\end{array}$ \\
\hline $\begin{array}{l}++ \\
++ \\
++ \\
++ \\
++\end{array}$ & $\begin{array}{l}0 \\
0 \\
0 \\
0 \\
0\end{array}$ & $\begin{array}{l}\mathbf{0} \\
\mathbf{0} \\
\mathbf{0} \\
\mathbf{0} \\
\pm\end{array}$ \\
\hline
\end{tabular}


Orthophosphate by itself did not alter the rates and yields of the oxidations and syntheses. Fluoride in the system without added orthophosphate brought about a significant elevation in the OGn value, attended by an almost fourfold rise in the value of the 'OGn: $\mathrm{CO}_{2}$ ' ratio (Table 7).

\section{Table 6. Inhibitors of cellulose synthesis}

Reaction mixtures $(20 \mathrm{ml}$.) contained $10 \mathrm{mg}$. of freeze-

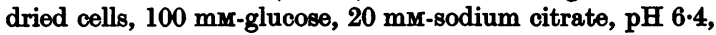
and inhibitors as listed. The gas phase was $\mathrm{O}_{\mathbf{2}}$. The reaction time was $60 \mathrm{~min}$.

Concn. (mM) of inhibitor causing inhibition of cellulose formation

\begin{tabular}{|c|c|c|c|}
\hline & & & \\
\hline Inhibition (\%) & $<20$ & $50 \pm 10$ & $>90$ \\
\hline hibitors & & & \\
\hline Cyanide & 0.01 & 0.06 & 1 \\
\hline$p$-Chloromercuribenzoate & - & 一 & $1 *$ \\
\hline$N$-Ethyl maleimide & - & - & $2^{*}$ \\
\hline 2:4-Dinitrophenol & $0 \cdot 1$ & 0.8 & 5 \\
\hline Thymol & - & - & 5 \\
\hline Fluoride & 0.5 & 3 & 10 \\
\hline Azide & 0.5 & 4 & 10 \\
\hline Toluenet & - & 5 & 一 \\
\hline Arsenate & $\mathbf{l}$ & 10 & - \\
\hline Iodoacetate & $2^{*}$ & 10 & - \\
\hline Formate & - & 10 & - \\
\hline Acetate & 5 & 30 & $50 \ddagger$ \\
\hline Pyruvate & - & 70 & $50 \ddagger$ \\
\hline Hydroxylamines & $\mathbf{5}$ & 100 & - \\
\hline Other compounds\| & 10 & - & - \\
\hline
\end{tabular}

* With fresh cells and with 50 mM-sodium phosphate, pH 6.8, as buffer under air as gas phase.

$\dagger$ Cellulose synthesis was also inhibited by other narcotics (ether, chloroform).

‡ With fresh fructose-grown cells and with $5 \mathrm{~mm}$ fructose as substrate, at $\mathrm{pH} 6$ under air as gas phase.

$\S \mathrm{pH} \mathrm{6.8.}$

II Malonate, arsenite (50 mM), 8-hydroxyquinoline, ethylenediamine tetra-acetate, inorganic ortho- and pyrophosphate, tetraethyl pyrophosphate; $\mathrm{Na}^{+}, \mathrm{K}+, \mathrm{Mg}^{2+}$ and $\mathrm{Mn}^{2+}$ ions (with $\mathrm{Cl}^{-}$ions at $\mathbf{4 0} \mathrm{mm}$ ). In addition it has been found that polylysine $(0.01 \%, w / v)$, some neutral detergents (sorbitan trioleate and polyoxymethylsorbitan monooleate, $2 \%, w / v)$ and streptomycin (5000 units $/ \mathrm{ml}$.) failed to inhibit synthesis significantly.
Arsenate. This anion inhibited cellulose synthesis. In accord with the assumption that the action resulted from competition between arsenate and orthophosphate, exogenous addition of phosphate was found to alleviate or abolish the arsenate effect (Fig. 4). That this effect was specific is shown by the observation that an antagonistic effect on arsenate was not given by glycerophosphate.

2:4-Dinitrophenol. Cellulose synthesis was suppressed and $\mathrm{CO}_{2}$ formation from glucose was

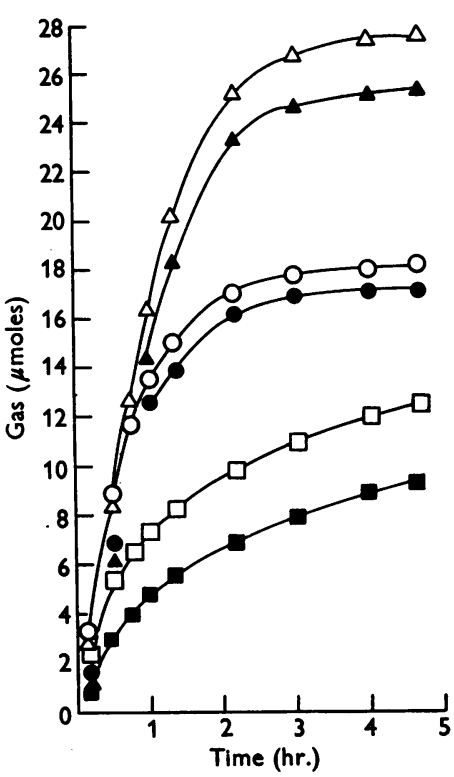

Fig. 3. Effects of inhibitors (fluoride and 2:4-dinitrophenol) on oxidation of glucose by $A$. xylinum. Reaction mixtures ( $2 \mathrm{ml}$.) contained $8 \mathrm{mg}$. of fresh cells, $2.5 \mathrm{~mm}$-glucose and 20 mx-sodium citrate, pH $6 \cdot 4$, with or without inhibitor. Substrate was introduced $60 \mathrm{~min}$. after contact of the cells with inhibitor. $\mathrm{O}, \mathrm{O}, \mathrm{O}_{2}$ and $\mathrm{CO}_{2}$ without additions or with 5 mm-orthophosphate $\left(\mathrm{P}_{i}\right)$ only; $\Delta, \Delta, \mathrm{O}_{8}$ and $\mathrm{CO}_{2}$ with 10 mM-fluoride plus 5 mM-P $\mathrm{P}_{i} ; \square, \square, \mathrm{O}_{2}$ and $\mathrm{CO}_{2}$ with 4 mM-DNP.

Table 7. Carbon balance of glucose metabolism by cells acting in the presence and absence of added orthophosphate, fluoride and 2:4-dinitrophenol

Reaction mixtures are described in Fig. 3. Carbon balances were made at the time of the conclusion of the manometric measurements (reaction time $4.5 \mathrm{hr}$.).

$\begin{array}{cccc}\text { Fluoride } & \mathbf{P}_{i} \S & \text { DPN } & \begin{array}{c}\text { O, uptake } \\ (\mu \text { moles })\end{array} \\ - & - & - & \mathbf{1 8 . 2} \\ - & + & - & \mathbf{1 8 . 0} \\ + & - & - & \mathbf{2 4 \cdot 2} \\ + & + & - & \mathbf{2 7 \cdot 6} \\ - & - & + & \mathbf{1 2 . 5}\end{array}$

* Actual moles of $\mathrm{CO}_{2}$ were six times these figures.

Products of reaction

(as $\mu$ moles of glucose)

$\begin{array}{cccc}\mathrm{CO}_{2}{ }^{*} & \text { OGn } & \text { Cellulose } & \begin{array}{c}\text { of carbon } \\ (\%)\end{array} \\ 2.9 & \text { Approx. 0.3 } & 2.0 & 104 \\ 2.8 & \text { Approx. 0.2 } & 2.1 & 102 \\ 3.6 & 1.2 \dagger & 0.0 & 96 \\ 4.25 & 0.5 & 0.0 & 95 \\ 1.55 & 3.2 \ddagger & 0.0 & 95\end{array}$

+ The ratio '2-OGn:5-OGn' was found to be 5

$\ddagger$ Calculated from the persisting copper-reducing power on the basis of the arbitrary assumption that the ratio '2OGn:5-OGn' in the suspension of DNP-poisoned cells, as in normal freeze-dried cells, was 2.

$\S \mathrm{P}_{i}=5$ mM-orthophosphate. 
markedly retarded by $4 \mathrm{~mm}-2: 4$-dinitrophenol (DNP) (Table 7). The kinetics of oxidation observed in the presence of the inhibitor were bimodal to both rate and R.Q. (Fig. 3). It can be noted that DNP resulted in marked elevation of both the absolute net amount of OGn formed and of the ratio 'OGn: $\mathrm{CO}_{2}$ ' (Table 7). Almost all of the amount of substrate which had not been converted by the end of the experiment into $\mathrm{CO}_{2}$ was $\mathrm{OGn}$.

Acetate and pyruvate. It has been observed that acetate, not itself incorporated into cellulose, promotes formation of cellulose from glucose in a growing culture (Greathouse et al. 1954). Accordingly, it seemed of interest to learn whether added acetate or acetate-forming pyruvate exert a similar effect in a suspension of washed cells. The unexpected finding was then made that synthesis from glucose and fructose in this system is not promoted but rather markedly inhibited by acetate and pyruvate.

As acetate can be oxidized rapidly, a high 'acetate: hexose' ratio seemed desirable to obtain a sustained inhibitory effect. In a typical instance, $50 \mathrm{~mm}$-acetate was incubated with $15 \mathrm{mg}$. (dry wt.) of fructose-grown fresh cells in 5 mm-fructose. The added acetate suppressed the synthesis during an observation period $(2 \mathrm{hr}$.) which permitted abundant cellulose formation in a control reaction mixture. Further experiments with the view to clarifying this remarkable inhibitory action are intended.

Arsenite. Cells in citrate buffer oxidized glucose and formed cellulose without attendant accumulation of a detectable amount of pyruvate in the

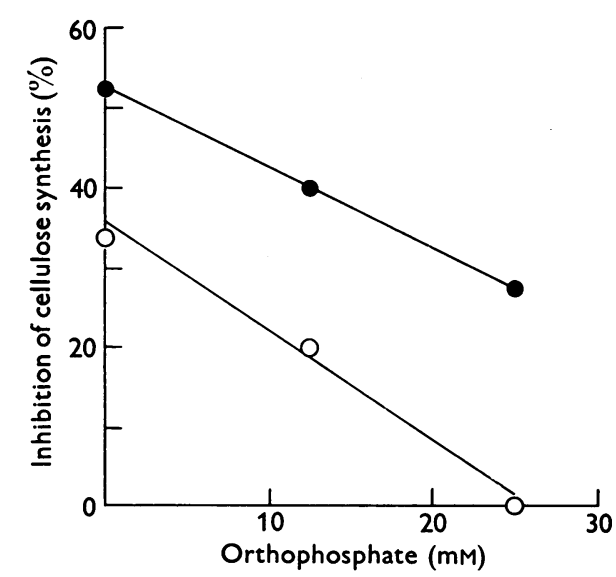

Fig. 4. Effect of phosphate on the inhibition of cellulose production by arsenate. Reaction mixtures (5 ml.) contained $13 \mathrm{mg}$. of freeze-dried cells, $150 \mathrm{~mm}$-glucose,

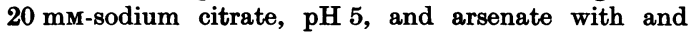
without orthophosphate. The gas phase was $\mathrm{O}_{2}$. The reaction time was $60 \mathrm{~min}$. $0,0,10$ and $2 \mathrm{~mm}$-arsenate respectively. medium of a standard-test system. In the presence of $5 \mathrm{~mm}$-arsenite, glucose was still converted into cellulose and presumably therefore was also oxidized, but pyruvate accumulation was not demonstrable.

Fluoroacetate. This agent in $10 \mathrm{~mm}$-concentration with an aerobic suspension of cells acting on glucose in 20 mM-sodium citrate solution, $\mathrm{pH} 5$, permitted cellulose formation and did not diminish or may have slightly enhanced the rate of production of $\mathrm{CO}_{2}$. In the absence of inhibitor, pyruvate and acetate were rapidly and completely oxidized to $\mathrm{CO}_{2}$. Fluoroacetate $(10 \mathrm{~mm})$ prevented the oxidation of acetate and stopped the pyruvate oxidation at a level corresponding to conversion of pyruvate into acetate.

\section{DISCUSSION}

In most species of cells, the aerobic metabolism of exogenous substrates sustains attendant reactions of assimilation leading to several products of reaction that are stored intracellularly. In the washed suspension of cells of $A$. xylinum, however, cellulose deposited extracellularly has been shown above to be formed in abundance (up to $45 \%$ of all added glucose) and to be the only quantitatively important product of the aerobic assimilation of exogenous glucose (Table 4). On these counts, $A$. xylinum might be regarded as a particularly suitable system for the study of mechanisms by which oxidative energy is harnessed to synthetic needs.

The information available does not suffice to permit the drawing of a detailed energy balance of oxidative assimilation of glucose by $A$. xylinum, but it may help to resolve the problem into more readily manageable components.

The highest observed value of the ratio 'cellulose: oxygen atom' in A. xylinum was never greater than about $0 \cdot 1$. A ratio as high as 3 might have been anticipated on the basis of the assumption that the energy of oxidation is channelled in this organism with ideal efficiency into synthesis of high-energy phosphate compounds $(\sim P)$ and that the ratio (monomer synthesized from glucose $):(\sim \mathrm{P}$ generated) can be l. Obviously the process of oxidative assimilation in $A$. xylinum falls far short of this ideal situation. Although the metabolism of ketoses (fructose, DHA) presumably does not involve OGn production, they were able to sustain vigorous cellulose production. Therefore, even if it is admitted that 'direct' oxidative steps in glucose metabolism are able to afford useful energy, the latter need not be regarded as obligatory for the synthesis of cellulose. An analogous assessment can be made of the probable value of pyruvate oxidation as a potential source of useful energy. Since $10 \mathrm{~mm}$ fluoroacetate exerted only a weak inhibitory action on the synthesis of cellulose, whereas it completely 
blocked acetate oxidation, it is suggested that the energy provided by pyruvate oxidation was not essential for the synthesis of cellulose.

The attempt to utilize substrate specificity data obtained with whole cells in order to construct a scheme of intermediate metabolism is complicated by the likelihood that selective-permeability factors are at play. That such factors were operative in fresh and even freeze-dried cells is indicated by the finding that some substrates ( $\alpha$-G 1-P, G 6-P, ATP, citrate and isocitrate) cleaved by disrupted-cell fractions (Gromet et al. 1957; unpublished experiments) were not attacked by suspensions of whole cells tested in medium at $\mathrm{pH} 6 \cdot 4$. Thus the failure of an added $P$ ester to yield cellulose need not detract from the likelihood that this ester is an intermediate of carbohydrate oxidation and an intracellular precursor of cellulose. Similarly, the incapacity of added ATP to sustain anaerobic synthesis does not indicate that ATP is not involved intracellularly in the channelling of energy. Finally, a non-oxidation of added citrate and isocitrate by cells does not deny the possibility that they possess a citrate cycle.

It has been shown above that glucose-grown cells of $A$. xylinum form gluconates (gluconate, 2 - and 5-OGn) from glucose and also carbon dioxide and cellulose from these substrates. In addition, fructose-grown cells also formed carbon dioxide and cellulose from fructose. Pyruvate, acetate and citrate-cycle intermediates, though rapidly oxidized to carbon dioxide by these cells (present results and unpublished experiments), gave no cellulose. Freeze-drying completely blocked the formation of cellulose and markedly lowered but did not abolish the formation of carbon dioxide from the oxogluconates, though it left almost intact the ability of the cells to form gluconates from glucose and to convert gluconate and glucose into carbon dioxide and cellulose. To rationalize these results it can be assumed that alternate pathways are available to the washed $A$. xylinum cell for the conversion of exogenous substrates into carbon dioxide and cellulose. A scheme of alternate pathways that takes into account the findings with whole cells, evidence derived from use of specifically labelled glucoses as substrates and observations on the enzymic constitution of a cell-free extract of the cells is presented in the next paper (Gromet et al. 1957).

The inhibitors of cellulose synthesis (Table 6) belong to a variety of chemical and physiological categories. They include cytochrome complexants (cyanide, azide), 'uncouplers' (DNP, azide), an analogue (arsenate) of phosphate, a halide (fluoride) which inhibits enolase and phosphatases as well as some other enzyme systems (cf. Aisenberg \& Potter, 1955), -SH reagents ( $p$-chloromercuribenzoate, $N$ - ethylmaleimide), 'narcotics' (toluene, ether, chloroform, thymol) and even some familiar oxidizable substances (pyruvate, acetate). It is apparent that an inhibitor could block synthesis by an effect exerted directly on a step in polymerization, by an effect exerted on a necessary transport mechanism, or by an effect on some step in substrate dissimilation or energy transmission on which synthesis may depend. The information available does not indicate the loci of action of individual inhibitors within the network of interlinked metabolic reactions. The case of fluoride may merit an added comment. As this agent permitted a normal rate of production of carbon dioxide, it probably did not interfere with the production of hexose-P. On the basis of the view that cellulose arises from hexose-P (Schramm et al. 1957), the inference can then be drawn that fluoride probably acted within the sequence: intracellular hexose-P $\rightarrow$ extracellular cellulose.

\section{Probable nature of an intracellular precursor of cellulose}

Evidence discussed elsewhere (Schramm et al. 1957) has suggested that cellulose arises in $A$. xylinum from the internal hexose-P pool of the cell by a reaction which does not necessarily involve cleavage of a carbon-carbon bond in the hexose radical. The finding (Gromet et al. 1957) that $A$. xylinum extract is richly endowed with phosphoglucomutase encourages speculation concerning the possibility that $\alpha-G 1-P$ is an intermediary in the formation of cellulose as of starch. A hypothesis, made particularly attractive by recent findings in green plants (cf. Altermatt \& Neish, 1956), suggests that UDPG might be the intermediary of cellulose formation in A. xylinum, but this is a view which can neither be clearly supported nor rejected on the basis of the limited information in our possession.

The degree of polymerization of $A$. xylinum cellulose has been shown to be nearly $3 \times 10^{3}$ (Ranby 1952). It is difficult to visualize diffusion of such a large particle across an intact cell wall which exhibits selective impermeability towards much smaller molecules. Moreover, cellulose did not accumulate within the cell interior (Hestrin \& Schramm, 1954). Thus if we suppose that cellulose is fully formed within the cell and then expelled, we assume that organelles for the active extrusion of cellulose into the medium exist and that cellulose is probably formed only within them. Such farreaching assumptions would be unsupported. There remain for consideration two alternatives: $(a)$ the exogenous substrate is transformed into extracellular cellulose by an exclusively extracellular sequence of reactions (the term 'extracellular' is used in a sense that comprises either reactions in the medium or on the outer surface of the cells); (b) the exogenous substrate enters the cell and is converted 
into a precursor which is excreted and converted into cellulose extracellularly. Were $(a)$ valid, it would be expected that added glucose 6-phosphate (G 6-P) and $\alpha$-G 1-P would be converted into cellulose and carbon dioxide. This was not the case. Hence it is deduced that the transformation of exogenous substrate into cellulose proceeded via an intracellular step (cf. also Hestrin et al. 1947). The familiar P-esters are not known to be readily moved into or out of an intact cell. It has been shown above that glucose 1-phosphates ( $\alpha$-G 1-P, $\beta$-G 1-P and UDPG) and G 4-P provided exogenously are not converted into cellulose on the outer surface of $A$. xylinum. Exogenously added G 6-P and the pentose-cycle intermediates formed from G 6-P by a fortified crude extract of $A$. xylinum were not converted into cellulose on the outer surface of the $A$. xylinum cell (Gromet et al. 1957). The possibility is therefore considered that the immediate cellulose precursor is not itself a P-ester difficult to transport but a derivative in which the $P$ group has been replaced or substituted by a radical whose presence facilitates transport across the cell wall. [This argument may also be pertinent to some other cases (e.g. Mager \& Aschner, 1947) in which internal hexose-P is the likely precursor of an extracellularly deposited high polymer.]

Cellulose appears to be deposited in green plants intracellularly. Therefore, in these, the above objection to the view that hexose-P is the immediate precursor of cellulose might not necessarily apply. However, very little is known as yet about the chemical mode of synthesis of cellulose (Greathouse, 1953; Brown \& Neish, 1954; Edelman, Ginzburg \& Hassid, 1955; Shafizadeh \& Wolfrom, 1955; Altermatt \& Neish, 1956) and mechanics of deposition (Muhlethaler, 1949; Preston \& Kuyper, 1951; Ranby, 1952; Steward \& Muhlethaler, 1953, 1954; Preston \& Astbury, 1954). What little evidence is available does not contradict the possibility that the chemical basis of the synthesis both in green plants and bacteria might be identical.

\section{SUMMARY}

1. Hexoses (glucose, fructose), three-carbon compounds (glycerol, dihydroxyacetone) and hexonates (gluconate, 2- and 5-oxogluconate) have been converted into cellulose by the action of washed cells of Acetobacter xylinum. The substrate range of the cells was a function of their history and the conditions in which they were assayed. Acetate, pyruvate and citrate-cycle intermediates were oxidized without attendant conversion into cellulose. Phosphate esters (including glucose 6-phosphate, $\alpha$-glucose 1-phosphate, $\beta$-glucose 1-phosphate and uridine diphosphoglucose) presumably failed to penetrate into the cells (fresh and freeze-dried).
Such esters, added exogenously, did not form cellulose.

2. The sole product of assimilation formed in substantial amount from glucose was cellulose. Glucose was converted via gluconate into 2- and 5oxogluconate. It was assimilated to cellulose and oxidized to carbon dioxide facultatively via these gluconates. The highest encountered value of the molar ratio "cellulose monomer : glucose oxidized to carbon dioxide' was $1 \cdot 7$, i.e. significantly greater than unity. In all instances only a small portion of the total energy liberated by concurrent oxidation of hexose was utilized for cellulose production ('cellulose monomer:oxygen atom' $<0 \cdot 1$ ). Exogenously provided adenosine triphosphate failed to sustain an anaerobic synthesis of cellulose. Electron acceptors other than oxygen permitted restricted oxidation of glucose and gluconate, presumably to oxogluconates, but such oxidation did not enable formation either of cellulose or of carbon dioxide.

3. Synthesis of cellulose from glucose has been blocked by appropriate respiration inhibitors, sulphydryl reagents, 'narcotics' and even by the oxidizable metabolites acetate and acetate-forming pyruvate. Synthesis was retarded by arsenate; this effect was alleviated by added orthophosphate. Whereas $10 \mathrm{~mm}$-fluoroacetate blocked acetate oxidation and caused that of pyruvate to cease at the level of acetate, it permitted both cellulose and carbon dioxide to be formed from glucose. Fluoride (10 mM) blocked the synthesis of cellulose but not the formation of carbon dioxide. 2:4-Dinitrophenol (4 mM) permitted oxogluconate production but blocked the formation of cellulose and retarded that of carbon dioxide from glucose.

4. The findings are in agreement with the suggestion that alternate metabolic pathways are available to the washed $A$. xylinum cell for the conversion of exogenous substrates into carbon dioxide and cellulose and with the hypothesis that an intracellular hexose phosphate is an intermediate in cellulose production.

This investigation and that in Part 4 were supported in part by a research grant (E 1494) from the National Institute of Allergy and Infectious Diseases of the National Institutes of Health, Public Health Service, Bethesda, Md., U.S.A.

\section{REFERENCES}

Aisenberg, A. C. \& Potter, V. R. (1955). J. biol. Chem. 215, 737.

Altermatt, H. A. \& Naish, A. C. (1956). Canad. J. Biochem. Physiol. 34, 405.

Barch, W. E. (1933). J. Amer. chem. Soc. 55, 3653.

Barclay, K. S., Bourne, E. J., Stacey, M. \& Webb, M. (1954). J. chem. Soc. p. 1501.

Bourne, E. J. \& Weigel, H. (1954). Chem. \& Ind., p. 132. Brown, A. J. (1886). J. chem. Soc. p. 432. 
Brown, S. A. \& Neish, A. C. (1954). Canad. J. Biochem. Physiol. 32, 170.

Butlin, K. R. (1938). Biochem. J. 32, 508.

Edelman, J., Ginzburg, V. \& Hassid, W. Z. (1955). J. biol. Chem. 213, 843.

Fitting, C. \& Doudoroff, M. (1952). J. biol.'Chem. 199, 153.

Friedemann, T. E. \& Haugen, G. E. (1943). J. biol. Chem. $147,415$.

Greathouse, G. A. (1953). Science, 117, 553.

Greathouse, G. A., Shirk, H. G. \& Minor, F. W. (1954). J. Amer. chem. Soc. 76, 5157.

Gromet, Z., Schramm, M. \& Hestrin, S. (1957). Biochem. J. 67, 679.

Hestrin, S., Aschner, M. \& Mager, J. (1947). Nature, Lond., $159,64$.

Hestrin, S. \& Schramm, M. (1954). Biochem. J. 58, 345.

Horrocks, R. H. (1949). Nature, Lond., 164, 444.

Jeanes, A., Wise, C. S. \& Dimler, R. J. (1951). Analyt. Chem. $23,415$.

Jones, A. R., Dowling, E. J. \& Skraba, W. J. (1953). Analyt. Chem. 25, 394.

Katznelson, H., Tanenbaum, S. W. \& Tatum, E. L. (1953). J. biol. Chem. 204, 43.

Kaushal, R. \& Walker, T. K. (1951). Biochem. J. 48, 618. Khouvine, Y. (1936). Bull. Soc. Chim. biol., Paris, 18, 1325. Khym, J. \& Cohn, W. (1953). J. Amer. chem. Soc. 75, 1153. Kluyver, A. \& Boezaardt, A. G. J. (1938). Rec. Trav. chim. Pays-Bas, 57, 609.

Kulka, D. \& Walker, T. K. (1954). Arch. Biochem. Biophys. $50,169$.
Lanning, M. C. \& Cohen, S. S. (1951). J.biol. Chem. 189, 109. Macleod, M. \& Robison, R. (1929). Biochem. J. 23, 517.

Mager, J. \& Aschner, M. (1947). J. Bact. 53, 283.

Muhlethaler, K. (1949). Biochim. biophys. Acta, 3, 527.

Nelson, N. (1944). J. biol. Chem. 153, 357.

Preston, R. D. \& Astbury, W.T. (1954). Nature, Lond., 173, 203.

Preston, R. D. \& Kuyper, D. (1951). J. exp. Bot. 2, 247.

Ranby, B. G. (1952). Ark. Kemi, 14, 249.

Schramm, M. (1956). Analyt. Chem. 28, 963.

Schramm, M., Gromet, Z. \& Hestrin, S. (1957). Nature, Lond., 179, 28.

Schramm, M. \& Hestrin, S. (1954a). J. gen. Microbiol. 11, 123.

Schramm, M. \& Hestrin, S. (1954b). Biochem. J. 56, 163.

Shafizadeh, F. \& Wolfrom, M. L. (1955). J. Amer. chem. Soc. 77, 5182.

Stacey, M. (1954). Advanc. Enzymol. 15, 315.

Stephenson, M. (1949). Bacterial Metabolism, p. 107. London: Longmans, Green and Co.

Steward, F. C. \& Muhlethaler, K. (1953). Ann. Bot., N.S., 17, 295.

Steward, F. C. \& Muhlethaler, K. (1954). Nature, Lond.,173, 203.

Tarr, H. L. A. \& Hibbert, H. (1931). Canad. J. Res. 4, 372.

Ujejski, L. \& Waygood, E. R. (1954). Canad. J. Chem. 32 , 14.

Wood, W. A. (1955). Bact. Rev. 19, 222.

Wright, H. B. \& Walker, T. K. (1955). Chem. \& Ind. p. 18.

\title{
Synthesis of Cellulose by Acetobacter xylinum
}

\section{ENZYME SYSTEMS PRESENT IN A CRUDE EXTRACT OF GLUCOSE-GROWN CELLS}

\author{
By Z. GROMET, M. SCHRAMM AND SHLOMO HESTRIN \\ Laboratory of Microbiological Chemistry, Department of Biochemistry, \\ Hebrew University-Hadassah Medical School, Jerusalem, Israel
}

\section{(Received 16 May 1957)}

The synthesis of cellulose from glucose by washed cells of Acetobacter xylinum has been shown to be conditional upon a concurrent oxidative process (Hestrin, Aschner \& Mager, 1947; Schramm, Gromet \& Hestrin, $1957 a, b)$. To understand the synthesis, a knowledge of the nature of the oxidative process seemed desirable. Some of the reactions of glucose oxidation that occur in an extract of $A$. xylinum cells are demonstrated in this paper.

\section{METHODS AND MATERIALS}

A. xylinum extracts. All operations were carried out in the cold room. Cell-free extracts were prepared from washed A. xylinum cells harvested from glucose medium (Schramm et al. $1957 b$ ) as follows.

(a) 'Alumina' extract: Freeze-dried cells (100 mg.) were triturated in a hand mortar with $300 \mathrm{mg}$. of alumina (Alumina A-301, Alcoa Ltd., Pittsburgh, Pa., U.S.A.) for $10 \mathrm{~min}$. Then
$3 \mathrm{ml}$. of $0.04 \mathrm{M}$-sodium citrate buffer, $\mathrm{pH} 6.4$, was added to the mixture. After $10 \mathrm{~min}$. the suspension was centrifuged $(3000 \mathrm{~g}$ for $15 \mathrm{~min}$.) and the packed sediment was reextracted in $2 \mathrm{ml}$. of buffer. The supernatant fluids (about $4 \mathrm{ml}$.) were pooled and partially cleared by centrifuging (3000 $\mathrm{g}$ for $15 \mathrm{~min}$.). The turbid, slightly pink supernatant fluid was stored at $-20^{\circ}$.

(b) 'Mickle' extract: Cells (100 mg. dry wt.) were washed in water (10 ml.) and then suspended in $3 \mathrm{ml}$. of $0 \cdot 1 \mathrm{M}$-2-aminohydroxymethylpropane-1:3-diol (tris) buffer $\left(\mathrm{Cl}^{-}\right.$; $\mathrm{pH} \mathrm{7 \cdot 5)}$. Treatment in a Mickle tissue disintegrator (30 min. with about $1 \mathrm{~g}$. of Ballotini glass beads) served to disrupt the cells. This 'homogenate' was centrifuged ( $3000 \mathrm{~g}$ for $15 \mathrm{~min}$.), the sediment re-extracted in $2 \mathrm{ml}$. of buffer and the supernatant fluids (about $4 \mathrm{ml}$.) pooled and partially cleared $(3000 \mathrm{~g}$ for 15 min.). The product was an opalescent fluid. It formed $\mathrm{CO}_{2}$ oxidatively from glucose 6-phosphate (G 6-P) even after storage for 1 month at $-20^{\circ}$. Such extracts have been obtained from fresh cells, freeze-dried cells and from frozen cells. 